\title{
PENDEKATAN METODE KANO - QFD \\ UNTUK MENGUKUR PELAYANAN LABORATORIUM UJI
}

\author{
${ }^{1)}$ Titiek Koesdijati, ${ }^{2)}$ Tri Yusufi Rahmadhani \\ 1,2 Jurusan Teknik Industri, Fakultas Teknologi Industri, Universitas \\ PGRI Adi Buana Surabaya \\ Email : titikkoedijati@yahoo.com
}

\begin{abstract}
Abstrak
Kepuasan pelanggan merupakan hal yang sangat penting dalam pelayanan publik, terutama di Laboratorium Uji Kualitas Lingkungan BLH Provinsi Jawa Timur yang pelanggannya berasal dari berbagai macam perusahaan di Indonesia. Penelitian ini bertujuan untuk mengetahui kepuasan pelanggan terhadap pelayanan dan sumber daya manusia di laboratorium serta menentukan prioritas perbaikan untuk pengembangan laboratorium pada masa yang akan datang. Penelitian ini menggunakan metode Kano yang diintegrasikan ke dalam metode Quality Function Deployment (QFD) untuk menghasilkan prioritas perbaikan. Berdasarkan penelitian dan analisis data pada variabel pelayanan, terdapat empat bagian bernilai rata-rata 3,26 yang artinya pelanggan cukup puas dan enam bagian bernilai rata-rata 3,67 yang artinya pelanggan puas. Sedangkan pada variabel sumber daya manusia terdapat satu bagian bernilai rata-rata 3,41 yang artinya pelanggan cukup puas dan dua bagian bernilai rata-rata 3,64 yang artinya pelanggan puas, serta diikuti dengan delapan urutan prioritas perbaikan untuk pengembangan laboratorium pada masa yang akan datang.
\end{abstract}

Kata kunci : Kepuasan pelanggan, Kano, QFD.

\begin{abstract}
Customer satisfaction is very important in public service, especially in the environmental quality testing laboratory of BLH East Java Province whose customers came from various companies in Indonesia. This study aimed to determined customer satisfaction in service and human resources of the laboratory and also the priority of improvement for the development of the laboratory in the future. This study used Kano method which is integrated into Quality Function Deployment (QFD) method to obtain improvement priority. Based on the processing and data analysis on service variable, there were four parts worth an average of 3,26 which meant the customers were quite satisfied and six parts worth an average of 3,67 which meant the customers were satisfied. While on the human resource variable, there was one part worth an average of 3,41 which meant the customers were quite satisfied and two parts worth an average of 3,64 which meant the customers were satisfied, followed by eight priority improvements for the development of BLH East Java Province testing laboratory in the future.
\end{abstract}

Keywords : Customer satisfaction, Kano, QFD.

\section{PENDAHULUAN}

Di Indonesia terdapat berbagai macam perusahaan atau instansi pelayanan publik baik milik pemerintah maupun swasta yang saling bersaing untuk memberikan yang terbaik kepada pelanggan dalam berbagai bidang, dengan tujuan menjadi pihak yang paling dipercaya untuk memenuhi segala kebutuhan pelanggan dan dituntut harus memiliki pengembangan di setiap bidang kerjanya sehingga dapat 
memperbaiki dan meningkatkan kualitas layanan.

Pengukuran kualitas pelayanan dapat dilakukan dan dianalisis serta dijadikan acuan, guna mengetahui bagian yang perlu diperbaiki atau dikembangkan dari layanan Laboratorium Uji Kualitas Lingkungan BLH Provinsi Jawa Timur. Selain itu perlu mencari solusi yang bisa dilakukan agar dapat memperbaiki pelayanan dan sumber daya manusianya serta urutan prioritas perbaikan sebagai bentuk pengembangan laboratorium pada masa yang akan datang dan memberikan kepuasan lebih kepada pelanggan di Laboratorium tersebut.

\section{METODE}

Penelitian ini diawali dengan pengumpulan data melalui kuisener dan selanjutnya diolah dengan metode Kano dan QFD. Adapun langkah penelitian yang dilakukan sebagai berikut :

\section{Pengumpulan Data}

Pengumpulan data dilakukan dengan menyebarkan kuesioner kepada pelanggan yang selalu menggunakan laboratorium tersebut dan berasal dari berbagai macam perusahaan atau instansi di Indonesia. Kuisener berisi tentang kategori atau atribut yang berhubungan dengan sumber daya manusia dan pelayanan dari laboratorium tersebut. Penilaian dalam kuisener dimulai dari divisi penerima sampel, analis sampel serta sistem dan manajemen dari pelayanan laboratorium tersebut. Hasil kuisener setelah dikelompokan dilakuan Uji Validitas dan Uji Reliabilitas menggunakan software SPSS 16.0.

\section{Metode Kano}

Pengolahan data menggunakan metode Kano, diawali dengan menentukan Kategori Analisis Kano, menghitung jumlah masing-masing kategori Kano dalam setiap atribut kebutuhan pelanggan / konsumen, mengklasifikasikan preferensi fungsional dan disfungsional setiap atribut berdasarkan nilai yang lebih banyak antara kategori $(\mathrm{A}+\mathrm{O}+\mathrm{M})$ dengan $(\mathrm{I}+\mathrm{R}+\mathrm{Q})$ seperti pada table 1 . Apabila atribut tersebut lebih banyak berkategori $\mathrm{A}, \mathrm{O}$, atau $\mathrm{M}$, maka atribut tersebut membutuhkan perbaikan atau pengembangan dan dapat dilanjutkan ke dalam metode QFD.

Tabel 1. Penentuan Kategori Metode Kano

\begin{tabular}{|c|c|c|c|c|c|c|}
\hline \multirow{2}{*}{\multicolumn{2}{|c|}{ Kebutuhan Konsumen }} & \multicolumn{5}{|c|}{ Disfungsional (Negatif) } \\
\hline & & 1 & 2 & 3 & 4 & $\begin{array}{c}5 \\
5\end{array}$ \\
\hline \multirow{6}{*}{$\begin{array}{l}\text { Fungsional } \\
\text { (Positif) }\end{array}$} & 1. Suka & Q & A & A & A & $\mathrm{O}$ \\
\hline & 2. Mengharap & $\mathrm{R}$ & I & I & I & M \\
\hline & 3. Netral & $\mathrm{R}$ & I & I & I & M \\
\hline & 4. Toleransi & $\mathrm{R}$ & I & I & I & $\mathrm{M}$ \\
\hline & 5. Tidak suka & $\mathrm{R}$ & $\mathrm{R}$ & $\mathrm{R}$ & $\mathrm{R}$ & Q \\
\hline & $\begin{array}{l}\text { Keterangan : } \\
\mathrm{Q}=\text { Question } \\
\mathrm{R}=\text { Reverse } \\
\mathrm{A}=\text { Attractiv } \\
\mathrm{O}=\text { One dim } \\
\mathrm{I}=\text { Indifferer } \\
\mathrm{M}=\text { Must be }\end{array}$ & $\begin{array}{l}\text { (diragu } \\
\text { undura } \\
\text { narik) } \\
\text { nal (sa } \\
\text { sa saja } \\
\text { arusan) }\end{array}$ & kuran) & & & \\
\hline
\end{tabular}


Titiek Koesdijati, \& Tri Yusufi Rahmadhani : Pendekatan Metode Kano - Qfd Untuk Mengukur Pelayanan Laboratorium Uji

\section{Analisis Quality Function Deployment (QFD)}

Mencari prioritas perbaikan dengan metode QFD (Quality Function Deployment) melalui HOQ (House Of Quality), menggunakan atribut hasil dari metode Kano yang berkategori A (Attractive), O (One dimensional), dan M (Must be) sebagai atribut pada Voice Of Customer / Customer need dalam House Of Quality (HOQ)seperti yang dijelaskan pada gambar 1.

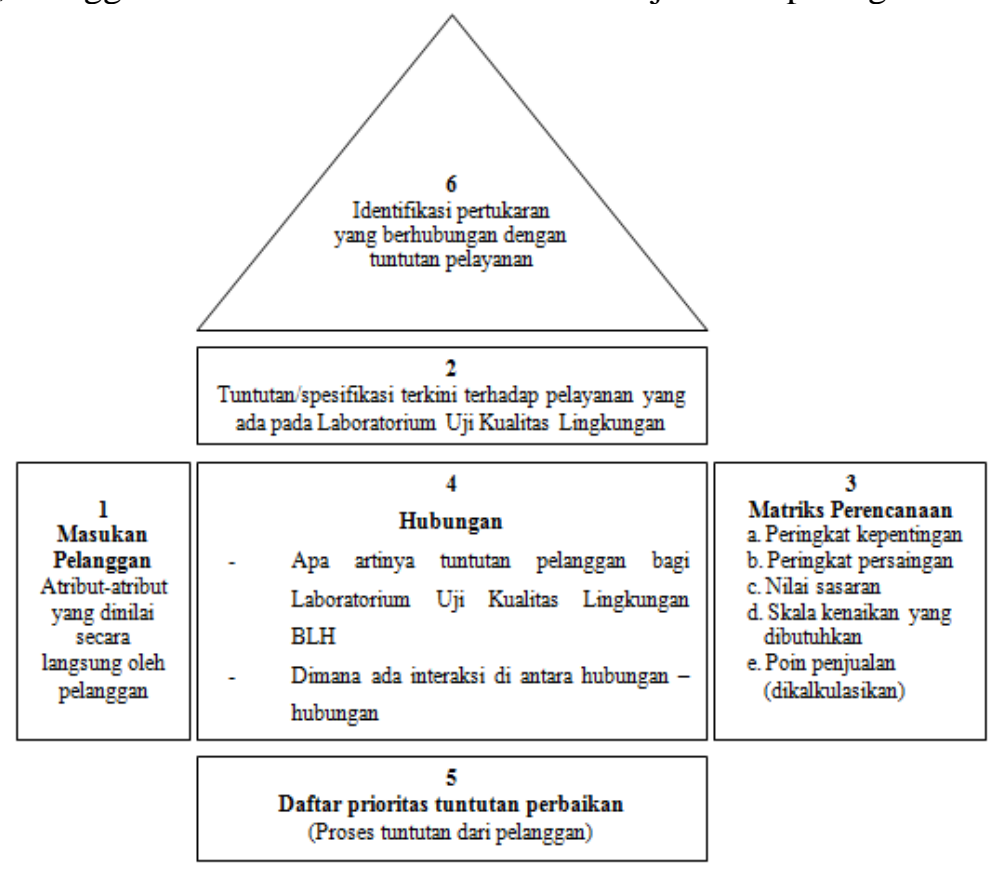

Gambar 1. House Of Quality (HOQ)

\section{HASIL DAN PEMBAHASAN}

\section{Pengolahan data}

Dari hasil kuesioner yang telah disebarkan, dalam Uji Realibilitas terdapat 2 dimensi yang cukup reliabel yaitu Tingkat Kepentingan dan Penilaian Laboratorium BLH serta 3 dimensi yang reliabel yaitu Penilaian Laboratorium Lainnya, Kebutuhan Konsumen Fungsional dan Kebutuhan Konsumen Disfungsional. Kelima dimensi tersebut dapat dipercaya untuk menunjukkan keadaan yang sebenarnya sehingga tidak perlu dilakukan penyebaran kuesioner ulang dan dapat dipertanggung jawabkan.
Selanjutnya hasil Uji Validitas menunjukkan bahwa semua atribut pernyataan dari dimensi Penilaian Laboratorium Lainnya memiliki keputusan Tolak $\mathrm{H}_{0}$ dan kesimpulan valid, sehingga dimensi tersebut tidak perlu dilakukan penyebaran kuesioner ulang dan dapat dilanjutkan ke dalam analisis selanjutnya.

\section{Hasil Analisis Kano}

Hasil kuesioner dari 70 responden dengan 13 atribut dapat dianalisa dengan menggunakan metode Kano dan hasilnya dapat dilanjutkan menggunakan metode QFD seperti pada table 2. 
Titiek Koesdijati, \& Tri Yusufi Rahmadhani : Pendekatan Metode Kano - Qfd Untuk Mengukur Pelayanan Laboratorium Uji

Tabel 2. Hasil Analisis Kano

\begin{tabular}{|c|c|c|c|c|c|}
\hline No & Atribut & $(\mathrm{A}+\mathrm{O}+\mathrm{M})$ & $(I+R+Q)$ & Total & Kesimpulan \\
\hline 1 & Persyaratan pelayanan & $(19+7+20)$ & $(24+0+0)$ & 70 & Dilanjutkan Ke Dalam Analisis QFD \\
\hline 2 & Biaya pengujian sampel uji & $(24+3+16)$ & $(27+0+0)$ & 70 & Dilanjutkan Ke Dalam Analisis QFD \\
\hline 3 & Kelen gekanan dan keielasan sertifikat pen gutian, & $(14+4+26)$ & $(26+0+0)$ & 70 & Dilanjutkan Ke Dalam Analisis QFD \\
\hline 4 & Informasi mengenai jatuh terpo pen iriman sanpel uji & $(28+4+14)$ & $(24+0+0)$ & 70 & Dilanjutkan Ke Dalam Analisis QFD \\
\hline 5 & Kesesuaian jadwal penerimaan sampel ui & $(15+4+21)$ & $(30+0+0)$ & 70 & Dilanjutkan Ke Dalam Analisis QFD \\
\hline 6 & Proses penerimaan sampel $u_{j i}$ & $(17+8+31)$ & $(14+0+0)$ & 70 & Dilanjutkan Ke Dalam Aualisis QFD \\
\hline 7 & Proses pembayaran biaya penguiian & $(11+10+29)$ & $(20+0+0)$ & 70 & Dilanjutkan Ke Dalam Aualisis QFD \\
\hline 8 & Informasi mengenai hasil penguiian sesuai baku mutu & $(21+6+17)$ & $(26+0+0)$ & 70 & Dilanjutkan Ke Dalam Aualisis QFD \\
\hline 9 & Informasi apabila sampel telah selesai dirji & $(18+6+32)$ & $(14+0+0)$ & 70 & Dilanjutkan Ke Dalam Avalisis QFD \\
\hline 10 & Ketepatan waktu proses pen gu ian & $(34+3+16)$ & $(17+0+0)$ & 70 & Dilanjutkan Ke Dalam Analisis QFD \\
\hline 11 & Keielasan informasi dari petugas. & $(22+7+20)$ & $(21+0+0)$ & 70 & Dilanjutkan Ke Dalam Analisis QFD \\
\hline 12 & Kesopanan dan keramahan Petugas & $(28+5+12)$ & $(25+0+0)$ & 70 & Dilanjutkan Ke Dalam Aualisis QFD \\
\hline 13 & $\begin{array}{l}\text { Komunikasi antara pelangan den gan laboratorium } \\
\text { penguiian }\end{array}$ & $(18+7+23)$ & $(22+0+0)$ & 70 & Dilanjutkan Ke Dalam Aualisis QFD \\
\hline
\end{tabular}

\section{Hasil Analisis Quality \\ Function Deployment (QFD) \\ Customer Needs and \\ Importance Level}

Segala persyaratan atau tuntutan yang dikehendaki pelanggan dan berhubungan dengan produk telah ditentukan, diantaranya tentang atribut-

$$
x=\frac{\sum_{i=1}^{n} D K i}{n}
$$

atribut sebagai Customer need / kebutuhan pelanggan.

Pada tahap pertama telah diperoleh importance level/tingkat kepentingan dari setiap atribut yang didapatkan dari hasil kuesioner dan telah diklasifikasikan melalui metode Kano, atau dapat disebut juga dengan atribut WHATs, yang dilakukan dengan cara :

dimana : $\quad$ DKi $=$ Derajat kepentingan responden ke-i

$\mathrm{n} \quad=$ jumlah responden

\section{Technical Responses}

Pada langkah pertama, agar dapat memenuhi kepuasan pelanggan, diusahakan spesifikasi kinerja terkini yang mensyaratkan pihak Laboratorium untuk melakukan hal yang sama. Langkah ini digambarkan pada bagian plafon/langit-langit rumah pada HOQ (House Of Quality).

Langkah ke dua, berisi tentang apa saja yang dapat dilakukan untuk memperbaiki setiap atributyang ada pada langkah ke satu. Atribut-atribut pada tahapan ini disebut juga dengan atribut $\mathrm{HOWs}$.

Selanjutnya dapat dilihat pada tabel 3 tentang respon teknik, menunjukkan banyak hal yang harus dilakukan untuk meningkatkan kepuasan pelanggan pada setiap atribut pelayanan Laboratorium. Semua respon teknik tersebut diharapkan dapat segera dilakukan, akan tetapi pada analisis selanjutnya akan dipilih satu prioritas yang harus didahulukan penerapannya. 
Titiek Koesdijati, \& Tri Yusufi Rahmadhani : Pendekatan Metode Kano - Qfd Untuk Mengukur Pelayanan Laboratorium Uji

Tabel 3. Respon Teknik

\begin{tabular}{cc}
\hline No & Respon Teknik \\
\hline 1 & Memiliki alur proses pengujian yang baik \\
2 & Selektif dalam memilih tenaga kerja \\
3 & Mencatat penggunaan bahan kimia untuk \\
analisa sampel uji \\
4 & Memberikan respon balik ke pelanggan \\
5 & tentang hasil pengujian \\
6 & Mengunjungi perusahaan pelanggan \\
7 & Meminimalisir pengulangan pengujian \\
8 & Menawarkan kontrak pengujian kepada \\
pelanggan \\
pentumkan basan hasil pada sertifikat \\
pengujian
\end{tabular}

\section{Nilai Sasaran / Target}

Pada tahap ini, diberikan suatu nilai sebenarnya yang harus dicapai dalam setiap atribut. Nilai tersebut diambil berdasarkan analisis yang telah dilakukan sebelumnya.
Pada tabel 4. terdapat 2 atribut yang bernilai lebih dari lainnya $(4,2)$ yaitu atribut biaya pengujian sampel uji dan ketepatan waktu proses pengujian. Nilai pada kedua atribut tersebut berdasarkan pada analisis tingkat kepentingan.

Tabel 4. Nilai Sasaran

\begin{tabular}{clc} 
No. & \multicolumn{1}{c}{ Atribut } & Nilai Sasaran \\
\hline & \multicolumn{1}{c}{ Pelayanan } \\
1. & Persyaratan pelayanan & 4,0 \\
2. & Biaya pengujian sampel uji & 4,2 \\
3. & Kelengkapan dan kejelasan sertifikat pengujian & 4,0 \\
4. & Informasi mengenai jatuh tempo pengiriman sampel uji & 4,0 \\
5. Kesesuaian jadwal penerimaan sampel uji & 4,0 \\
6. & Proses penerimaan sampel uji & 4,0 \\
7. & Proses pembayaran biaya pengujian & 4,0 \\
8. & Informasi mengenai hasil pengujian sesuai baku mutu & 4,0 \\
9. & Informasi apabila sampel telah selesai diuji & 4,0 \\
10. & Ketepatan waktu proses pengujian & 4,2 \\
& $\quad$ Sumber Daya Manusia & 4,0 \\
11. & Kejelasan informasi dari petugas & 4,0 \\
12. Kesopanan dan keramahan Petugas & 4,0 \\
13. & Komunikasi antara pelanggan dan laboratorium pengujian & \\
\hline
\end{tabular}

\section{Improvement Ratio (Rasio Perbaikan)}

Setiap atribut memiliki penilaian yang berbeda-beda dari pelanggan, hal tersebut berdasarkan kepuasan setiap pelanggan terhadap atribut pelayanan yang diberikan oleh pihak Laboratorium
BLH. Rasio perbaikan diperoleh dari data kepuasan pelanggan terhadap Laboratorium BLH dengan nilai target yang sudah dianalisis sebelumnya. Berikut cara untuk menghitung rasio perbaikan dari masing-masing atribut : 
Titiek Koesdijati, \& Tri Yusufi Rahmadhani : Pendekatan Metode Kano - Qfd Untuk Mengukur Pelayanan Laboratorium Uji

$$
\text { Rasio Perbaikan }=\frac{\text { Nilai Target }}{\text { Nilai Kepuasan }}
$$

\section{Sales Point}

Menurut Cohen L (1995) dalam bukunya How To Make QFD For You terdapat 3 macam sales point yaitu :

Tabel 5. Sales point

\begin{tabular}{cc}
\hline Nilai & Arti \\
\hline 1 & Tidak ada sales \\
& point \\
1,2 & Sales point \\
& sedang \\
1,5 & Sales point $\mathrm{kuat}$ \\
\hline
\end{tabular}

Pada bagian ini, menganalisis seberapa besar nilai jual suatu atribut didalam lingkungan Laboratorium BLH dan hasil sales point seperti pada tabel 6

Tabel 6. Hasil Analisis Sales Point Tiap Atribut

\begin{tabular}{clc}
\hline No. & \multicolumn{1}{c}{ Atribut } & Sales Point \\
\hline & \multicolumn{1}{c}{ Pelayanan } \\
1. & Persyaratan pelayanan & 1,2 \\
2. & Biaya pengujian sampel uji & 1,5 \\
3. & Kelengkapan dan kejelasan sertifikat pengujian & 1,2 \\
4. & Informasi mengenai jatuh tempo pengiriman sampel uji & 1,2 \\
5. & Kesesuaian jadwal penerimaan sampel uji & 1,2 \\
6. & Proses penerimaan sampel uji & 1,2 \\
7. & Proses pembayaran biaya pengujian & 1,2 \\
8. & Informasi mengenai hasil pengujian sesuai baku mutu & 1,5 \\
9. & Informasi apabila sampel telah selesai diuji & 1,2 \\
10. & Ketepatan waktu proses pengujian & 1,5 \\
& $\quad$ Sumber Daya Manusia & 1,2 \\
11. & Kejelasan informasi dari petugas & 1,2 \\
12. & Kesopanan dan keramahan Petugas & 1,2 \\
13. & Komunikasi antara pelanggan dengan laboratorium pengujian \\
\hline
\end{tabular}

Pada tabel 6. terdapat 3 atribut yang bernilai 1,5 lebih dari lainnya yaitu atribut biaya pengujian sampel uji, ketepatan waktu proses pengujian, dan informasi mengenai hasil pengujian sesuai baku mutu. Pada atribut nomor 2 dan 10 diberikan nilai 1,5 karena pada analisis tingkat kepentingan sehingga rasio perbaikan 2 atribut tersebut memiliki nilai yang lebih besar daripada atribut lainnya.

Sedangkan pada atribut nomor 8 diberikan nilai 1,5 (sales point kuat) karena berdasarkan hasil wawancara dengan pelanggan, terdapat rasa kecewa tentang hasil pengujiannya tidak sesuai dengan baku mutu. 


\section{Bobot dan Normalisasi Bobot}

Pada pembentukan HOQ (House Of Quality) dalam metode QFD (Quality Function Deployment), sebelum menentukan nilai hubungan antara atribut dengan respon teknis, perlu dihitung terlebih dahulu bobot dari masing-masing atribut yang akan digunakan untuk perhitungan selanjutnya. Berikut cara untuk menghitung bobot dan normalisasi bobot

Bobot $=$ Tingkat kepentingan $\mathrm{x}$ Rasio perbaikan $\mathrm{x}$ Sales point

Normalisasi bobot $=\underline{\text { Bobot }}$

Total Bobot

\section{Hubungan}

Hubungan sebab akibat yang ditimbulkan antara kebutuhan dan keinginan konsumen (customer needs) dengan karakteristik teknik (technical respons). Hubungan tersebut terbentuk antara persyaratan pelanggan dan pendeskripsian teknis, sehingga dapat saling mempengaruhi.. Setiap hubungan pada dua bagian ini akan diberi simbol dengan nilai yang berbeda-beda.

Menurut Toni W (2011) dalam bukunya Manajemen Kualitas Jasa, hubungan memiliki 3 simbol dengan nilai yang berbeda, dapat diihat pada tabel 7.

Tabel 7. Nilai Hubungan

\begin{tabular}{cccl}
\hline No & Simbol & Nilai Numerik & \multicolumn{1}{c}{ Pengertian } \\
\hline 1 & $\bigcirc$ & 9 & Sangat kuat hubungannya \\
2 & $\bigcirc$ & 3 & Hubungannya sedang \\
3 & $\bigwedge$ & 1 & Mungkin ada hubungan \\
\hline
\end{tabular}

Daftar prioritas tuntutan perbaikan

Bagian ini merupakan prioritas persyaratan dalam proses analisis QFD. Setiap hubungan memiliki nilai yang berbeda, sehingga pada hubungan yang memiliki nilai terbanyak / tertinggi akan dilakukan perbaikan terlebih dahulu (prioritas).
Pada analisis tahap ini peneliti menghitung jumlah nilai hubungan dari setiap respon teknik sebagai bentuk tindakan perbaikan dengan masingmasing atribut kemudian mencari prioritas mana yang harus didahulukan perbaikannya dimulai dengan nilai yang paling besar. Berikut cara mencari prioritas perbaikan :

Nilai parameter teknik $=$ bobot $\mathrm{x}$ nilai hubungan

Kepentingan relatif $=$ Jumlah nilai parameter teknik

$$
\text { Persentase prioritas }=\frac{\text { Kepentingan Relatif }}{\text { Total Kepentingan Relatif }} \times 100 \%
$$

\section{House Of Quality (HOQ)}

Langkah-langkah yang

telah dilakukan pada analisis

QFD selanjutnya dimasukkan dalam House Of Quality (HOQ) seperti pada gambar 2 berikut ini. 
Titiek Koesdijati, \& Tri Yusufi Rahmadhani : Pendekatan Metode Kano - Qfd Untuk Mengukur Pelayanan Laboratorium Uji

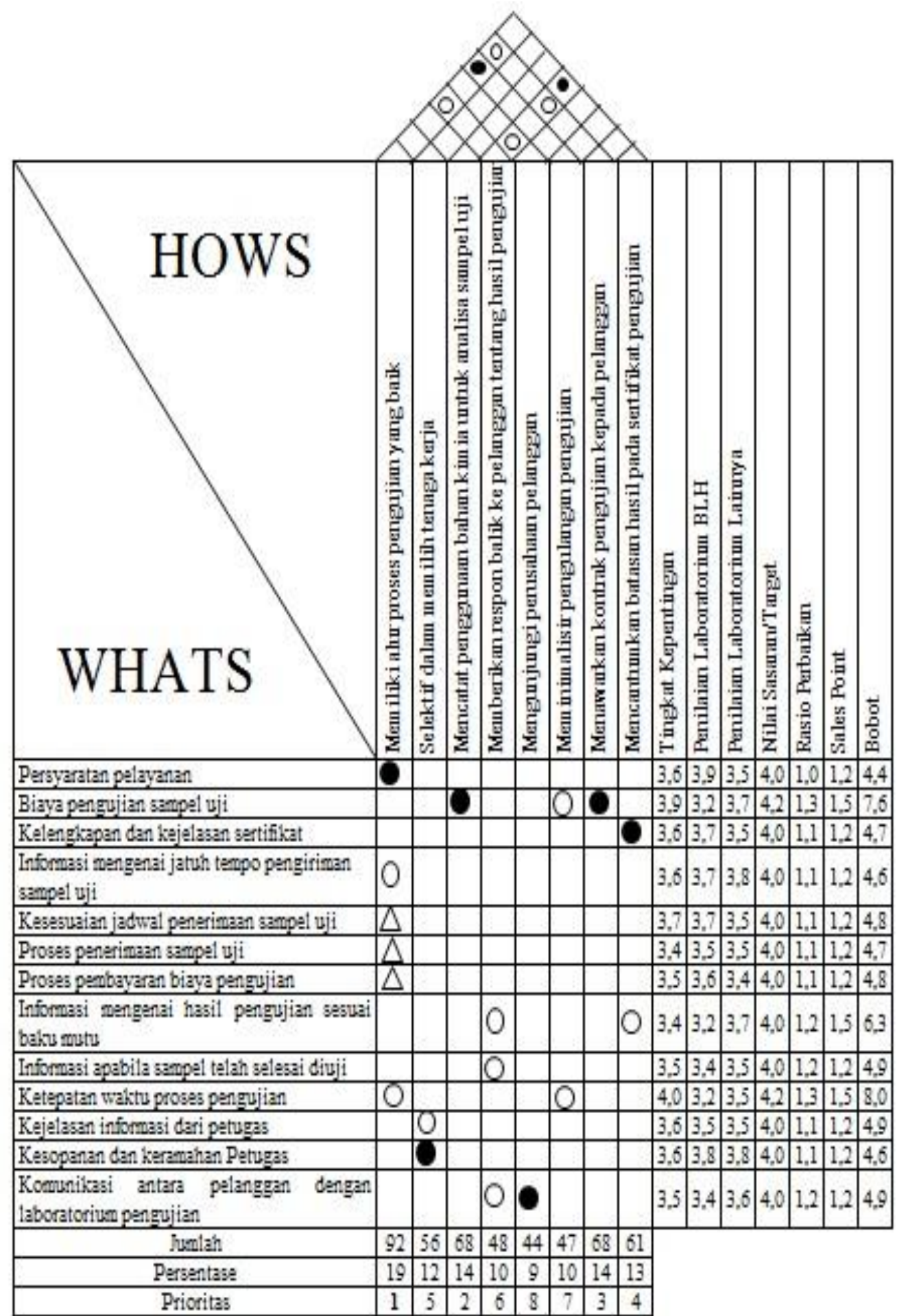

Gambar 2. Hasil HOQ Keseluruhan

Pada HOQ tersebut dapat dilihat hubungan yang sangat kuat antara atribut persyaratan pelayanan dengan solusi untuk memiliki alur proses pengujian yang baik dan begitu seterusnya.

\section{Solusi teknis perbaikan}

Nilai hubungan yang terdapat pada $\mathrm{HOQ}$, diperoleh 8 urutan prioritas perbaikan yang perlu perhatian yaitu :

1. Memiliki alur proses pengujian yang baik 
Titiek Koesdijati, \& Tri Yusufi Rahmadhani : Pendekatan Metode Kano - Qfd Untuk Mengukur Pelayanan Laboratorium Uji

2. Mencatat penggunaan bahan kimia untuk analisa sampel uji 3. Menawarkan kontrak pengujian kepada pelanggan 4. Mencantumkan batasan hasil pada sertifikat pengujian

5. Selektif dalam memilih tenaga kerja

6. Memberikan respon balik ke pelanggan tentang hasil pengujian

7. Meminimalisir pengulangan pengujian

8. Mengunjungi perusahaan pelanggan

Prioritas pertama merupakan solusi terbaik yang diberikan karena memiliki nilai kepentingan relatif cukup besar daripada prioritas yang lain. Berikut solusi untuk respon teknis perbaikan melalui alur pengujian yang baik seperti pada diagram alir gambar 3

a. Langkah pertama, petugas penerima akan menerima sampel uji tersebut baik dari pelanggan kontrak maupun pelanggan baru. Sampel tersebut diidentifikasi apakah tergolong limbah, air, atau tanah dan diberikan kode sebagai nomor antrian pengujian. Setelah itu sampel disimpan dalam tempat yang sesuai dengan jenis sampel yang telah diidentifikasi sebelumnya.

b. Langkah berikutnya, petugas analis mengambil sampel uji dari tempat yang ditentukan, lalu melakukan preparasi analisa. Setelah persiapan selesai, petugas analisa melakukan proses analisa sampel uji dengan parameter-parameter uji sesuai sesuai kebutuhan pelanggan tersebut dan dihitung hasilnya, dibandingkan dengan batasan hasil,

c. Apabila hasilnya belum masuk batasan yang ditentukan maka proses analisa akan diulang. Sebaliknya apabila sudah masuk batasan yang ditentukan, dapat dilaporkan kepada petugas untuk diterbitkan sertifikat pengujian dan nota pembayaran yang akan dikirim kepada pelanggan yang bersangkutan.

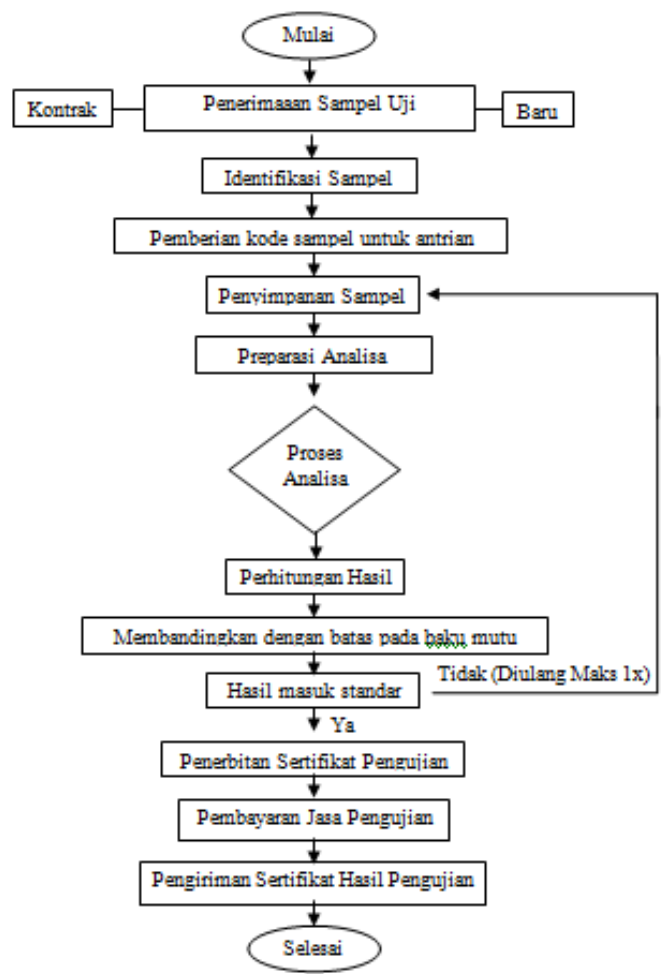

Gambar 3. Solusi Teknis Perbaikan 


\section{KESIMPULAN}

1) Pelayanan di laboratorium bernilai rata-rata sebesar 3 yang artinya pelanggan cukup puas pada bagian biaya pengujian sampel uji, informasi mengenai hasil pengujian sesuai baku mutu, informasi apabila sampel telah selesai diuji, dan ketepatan waktu proses pengujian. Pelayanan di laboratorium juga bernilai rata-rata sebesar 4 yang artinya pelanggan puas pada bagian persyaratan pelayanan, kelengkapan dan kejelasan sertifikat pengujian, informasi mengenai jatuh tempo pengiriman sampel uji, kesesuaian jadwal penerimaan sampel uji, proses penerimaan sampel uji, dan proses pembayaran biaya pengujian.

2) Sumber daya manusia di laboratorium bernilai rata-rata sebesar 3 yang artinya pelanggan cukup puas pada bagian komunikasi antara pelanggan dengan laboratorium pengujian. Sumber daya manusia juga bernilai rata-rata sebesar 4 yang artinya pelanggan puas pada bagian kejelasan informasi dari petugas, dan kesopanan dan keramahan petugas.

3) Analisa QFD menghasilkan 8 urutan prioritas perbaikan bagi Laboratorium BLH, dimulai dengan persentase yang paling besar yaitu :

1. Memiliki alur proses pengujian yang baik $(18,9 \%)$

2. Mencatat penggunaan bahan kimia analisa sampel uji $(14,1$ $\%)$

3. Menawarkan kontrak pengujian kepada pelanggan $(14,0 \%)$

4. Mencantumkan batasan hasil pada sertifikat pengujian $(12,6$ $\%)$

5. Selektif dalam memilih tenaga kerja $(11,6 \%)$

6. Memberikan respon balik ke pelanggan tentang hasil pengujian $(10,0 \%)$

7. Meminimalisir pengulangan pengujian $(9,6 \%)$

8. Mengunjungi perusahaan pelanggan $(9,1 \%)$

\section{DAFTAR PUSTAKA}

BLH, 2015. Survei Kepuasan Masyarakat (SKM), Surabaya : BLH.

Beckford, John L.W. (2002). Quality function deployment. New York: Rouledge.

Cohen, Lou. 1995. Quality function deployment : How to make QFD work of you. New York: Wesley Publishing Company.

Gasperz, V. (2002). Manajemen kualitas dalam industri jasa. Jakarta:Gramedia Pustaka Utama.

Mukarom, Zaenal. \& Wijaya, Muhibudin. 2015. Manajemen Pelayanan Publik, Bandung : Pustaka Setia.

Nasution, Nur. 2005. Manajemen Mutu Terpadu. Jakarta : Ghalia Indonesia

Nasution, M. N. 2005. Manajemen mutu terpadu (Total Quality Management) Edisi kedua. Jakarta : Ghalia Indonesia.

Sauerwein, E., Bailom, F., Matzler, K., and Hinterhuber, H. H. (1996). The Kano Model: How to Delight Your Customer. Production, I(9), 313-327.

Sugianto, Mikael. 2012. Mengolah Data Bisnis dengan SPSS 20, Semarang : Kompas Gramedia.

Tony, Wijaya. 2011. Manajemen kualitas jasa. Yogyakarta: PT. Index. 